\title{
DNA Methylation of the Angiotensinogen Gene, $A G T$, and the Aldosterone Synthase Gene, CYP11B2 in Cardiovascular Diseases
}

\author{
Yoshimichi Takeda ${ }^{1,2}$, Masashi Demura ${ }^{2}$, Takashi Yoneda ${ }^{3}(1)$ and Yoshiyu Takeda ${ }^{1,4, *}$ \\ 1 Department of Endocrinology and Metabolism, Kanazawa University Hospital, Kanazawa 920-8641, Japan; \\ bell_bey@hotmil.com \\ 2 Department of Hygiene, Graduate School of Medical Science, Kanazawa University, \\ Kanazawa 920-8641, Japan; m-demura@med.kanazawa-u.ac.jp \\ 3 Institute of Liberal Arts and Science, Kanazawa University, Kanazawa 920-8641, Japan; \\ endocrin@med.kanazawa-u.ac.jp \\ 4 Endocrine and Diabetes Center, Asanogawa General Hospital, Kanazawa 920-8621, Japan \\ * Correspondence: takeday@med.kanazawa-u.ac.jp; Tel.: +81-76-265-2252; Fax: +81-76-234-4251
}

check for updates

Citation: Takeda, Y.; Demura, M.; Yoneda, T.; Takeda, Y. DNA

Methylation of the Angiotensinogen Gene, $A G T$, and the Aldosterone Synthase Gene, CYP11B2 in Cardiovascular Diseases. Int. J. Mol. Sci. 2021, 22, 4587. https://doi.org/ $10.3390 /$ ijms 22094587

Academic Editor:

Michaela Adamcova

Received: 30 March 2021

Accepted: 22 April 2021

Published: 27 April 2021

Publisher's Note: MDPI stays neutral with regard to jurisdictional claims in published maps and institutional affiliations.

Copyright: (c) 2021 by the authors. Licensee MDPI, Basel, Switzerland. This article is an open access article distributed under the terms and conditions of the Creative Commons Attribution (CC BY) license (https:// creativecommons.org/licenses/by/ $4.0 /)$.

\begin{abstract}
Angiotensinogen (AGT) and aldosterone play key roles in the regulation of blood pressure and are implicated in the pathogenesis of cardiovascular diseases. DNA methylation typically acts to repress gene transcription. The aldosterone synthase gene CYP11B2 is regulated by angiotensin II and potassium. DNA methylation negatively regulates $A G T$ and CYP11B2 expression and dynamically changes in response to continuous promoter stimulation of each gene. High salt intake and excess circulating aldosterone cause DNA demethylation around the CCAAT-enhancer-binding-protein (CEBP) sites of the ATG promoter region, thereby converting the phenotype of AGT expression from an inactive to an active state in visceral adipose tissue and heart. A close association exists between low DNA methylation at CEBP-binding sites and increased $A G T$ expression in salt-sensitive hypertensive rats. Salt-dependent hypertension may be partially affected by increased cardiac AGT expression. CpG dinucleotides in the CYP11B2 promoter are hypomethylated in aldosterone-producing adenomas. Methylation of recognition sequences of transcription factors, including CREB1, NGFIB (NR4A1), and NURR1 (NR4A2) diminish their DNA-binding activity. The methylated CpG-binding protein MECP2 interacts directly with the methylated CYP11B2 promoter. Low salt intake and angiotensin II infusion lead to upregulation of CYP11B2 expression and DNA hypomethylation in the adrenal gland. Treatment with the angiotensin II type 1 receptor antagonist decreases CYP11B2 expression and leads to DNA hypermethylation. A close association between low DNA methylation and increased CYP11B2 expression are seen in the hearts of patients with hypertrophic cardiomyopathy. These results indicate that epigenetic regulation of both $A G T$ and CYP11B2 contribute to the pathogenesis of cardiovascular diseases.
\end{abstract}

Keywords: angiotensinogen; aldosterone; methylation; cardiovascular disease; salt

\section{Introduction}

The renin-angiotensin-aldosterone system (RAAS) plays an important role in the pathogenesis of cardiovascular diseases [1-3]. Angiotensinogen (AGT) is the only known substrate for renin that is the rate-limiting enzyme of the RAAS. AGT levels can control the activity of the RAS, and its upregulation may lead to elevated angiotensin peptide levels and increases in blood pressure (BP) and is implicated in cardiovascular injuries. The cross-talk of angiotensin II and aldosterone in the pathogenesis of hypertension and cardiovascular diseases has been proposed (Figure 1). Aldosterone affects not only the type1 angiotensin II receptor (AT1R) but also the angiotensin converting enzyme (ACE) and the renin receptor [4-8]. 


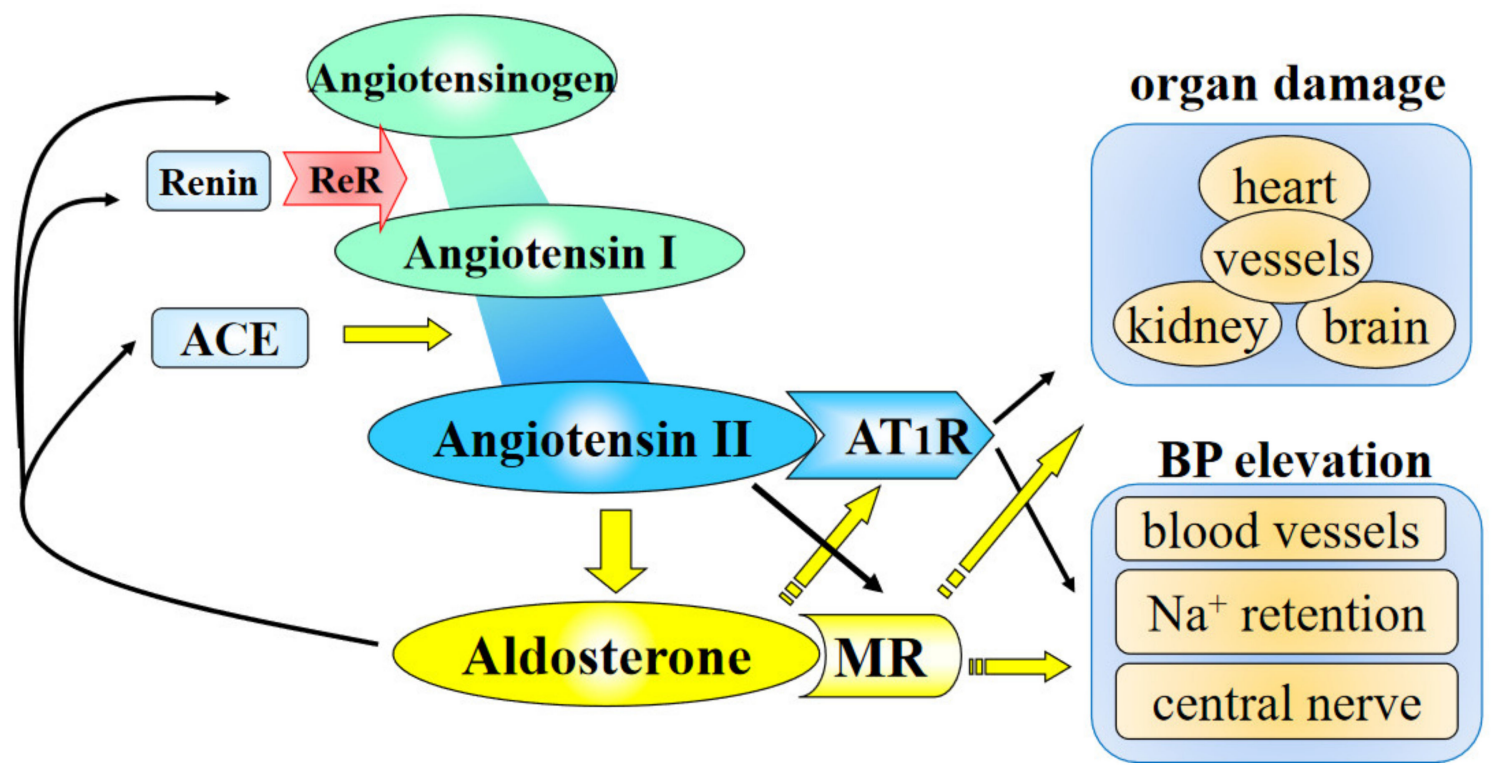

Figure 1. The cross-talk of angiotensin II and aldosterone in the pathogenesis of hypertension and cardiovascular diseases. Angiotensin II increases MR activity. Aldosterone affects not only AT1R but also ACE, renin and angiotensinogen. AT1R, angiotensin II type 1 receptor; MR, mineralocorticoid receptor; ACE, angiotensin converting enzyme.

Hypertensive mice that systemically express human renin and human AGT show elevated renal angiotensin II levels [9]. We have reported that renal AGT gene expression is increased in salt-sensitive hypertensive rats and treatment with the AT1R blocker (ARB) or mineralocorticoid receptor antagonist (MRA) decreases the AGT mRNA levels [10]. Recent studies on experimental animal models and transgenic mice have documented the involvement of the adipose AGT in the activation of the RAAS and the development of hypertension. This observation indicates that the adipose tissue-derived AGT contributes to circulating the AGT level and the resultant pathophysiology of obesity-related metabolic diseases [11-13].

Aldosterone is produced in the zona glomerulosa of the adrenal cortex by aldosterone synthase (CYP11B2) and is known to promote cardiac fibrosis and hypertrophy with concurrent elevation of inflammatory and oxidant signaling [14-17]. Aldosterone synthesis is regulated by angiotensin II and potassium. Patients with primary aldosteronism, have a higher incidence of myocardial infarction and stroke than do patients with essential hypertension [18-23]. Mineralocorticoid receptor antagonists (MRAs) have been shown to be effective in reducing the mortality and hospitalizations for heart failure (HF) in patients with chronic HF with a reduced left-ventricular ejection fraction (rEF) [24,25], and in patients with HFrEF early postmyocardial infarction [26-28]. Experimental animal data support a role for aldosterone in mediating cardiovascular and renal injuries. In saltsensitive hypertensive (SSH) rats, administration of the MRA greatly attenuated cardiac hypertrophy [29]. An important pathological effect of aldosterone in the heart has also been reported in experimental models of mineralocorticoid hypertension [30]. In these studies, prolonged exposure to aldosterone was associated with the development of myocardial hypertrophy and fibrosis.

DNA methylation is a stable, long-term epigenetic modification that affects gene expression without altering its DNA sequence [31,32]. In mammals, DNA methylation is a covalent modification that occurs primarily at a position on cytosine rings within $\mathrm{CpG}$ dinucleotides that usually represses gene transcription. Additionally, DNA hypermethylation in gene promoter regions generally silences genes. DNA methylation has a central role in the development and differentiation of mammalian cells. A logical connection between carcinogenesis and DNA methylation has been well established. Somatic DNA changes and dysregulation of DNA methylation have recently been demonstrated to be involved in the development of hypertension [33]. It is hypothesized that once DNA methy- 
lation patterns are established during cellular development, differentiation and disease progression, they are stably maintained. However, recent progress in this field has revealed DNA methylation pattern dynamics in response to various environmental stimuli $[34,35]$. Daily factors involved in the alteration of DNA methylation include chemicals, infection, smoking, exercise and learning. Lifestyle influences the metabolism via DNA methylation. These observations imply an association between DNA methylation dynamics and multifactorial lifestyle-related diseases, such as cardiovascular diseases, diabetes mellitus and dyslipidemia.

\section{Contribution of DNA Methylation to Human AGT Gene Transcription}

DNA methylation is generally involved in stabilizing the silent state of genes by either blocking DNA-binding transcription factors or recruiting methyl-CpG-binding domain (MBD) proteins, which favor the formation of the transcriptionally inactive forms of chromatin (heterochromatin). Among the MBD proteins, methyl-CpG-binding protein 2 (MECP2), MBD1 and MBD2 repress the transcription of methylated gene promoters. The human AGT promoter possesses a number of $\mathrm{CpG}$ dinucleotides that are targets for DNA methylation (Figure 2). The human AGT promoter which is located within a CCAAT enhancer-binding protein (CEBP)-binding site that contains a $\mathrm{CpG}$ dinucleotide at positions $-218 /-217$, is hypomethylated in tissues and cells with high AGT expression (liver, heart and HepG2 hepatocytes) but not in those with low expression (adrenal glands, leukocytes and adrenocortical H295R cells) [16]. Thus, the methylation status of a CpG dinucleotide within the CEBP-binding site appears to be inversely associated with AGT expression. In the human $A T G$ promoter, each of these sites, upstream stimulatory factor (USF)1/estrogen receptor (ESR)1, CEBPB/nuclear receptor (NR)3C1, hepatocyte nuclear factor (HNF)1A, 4A, USF1,2, NR2F1 and ESR1 contains each CpG dinucleotide (Figure 2).

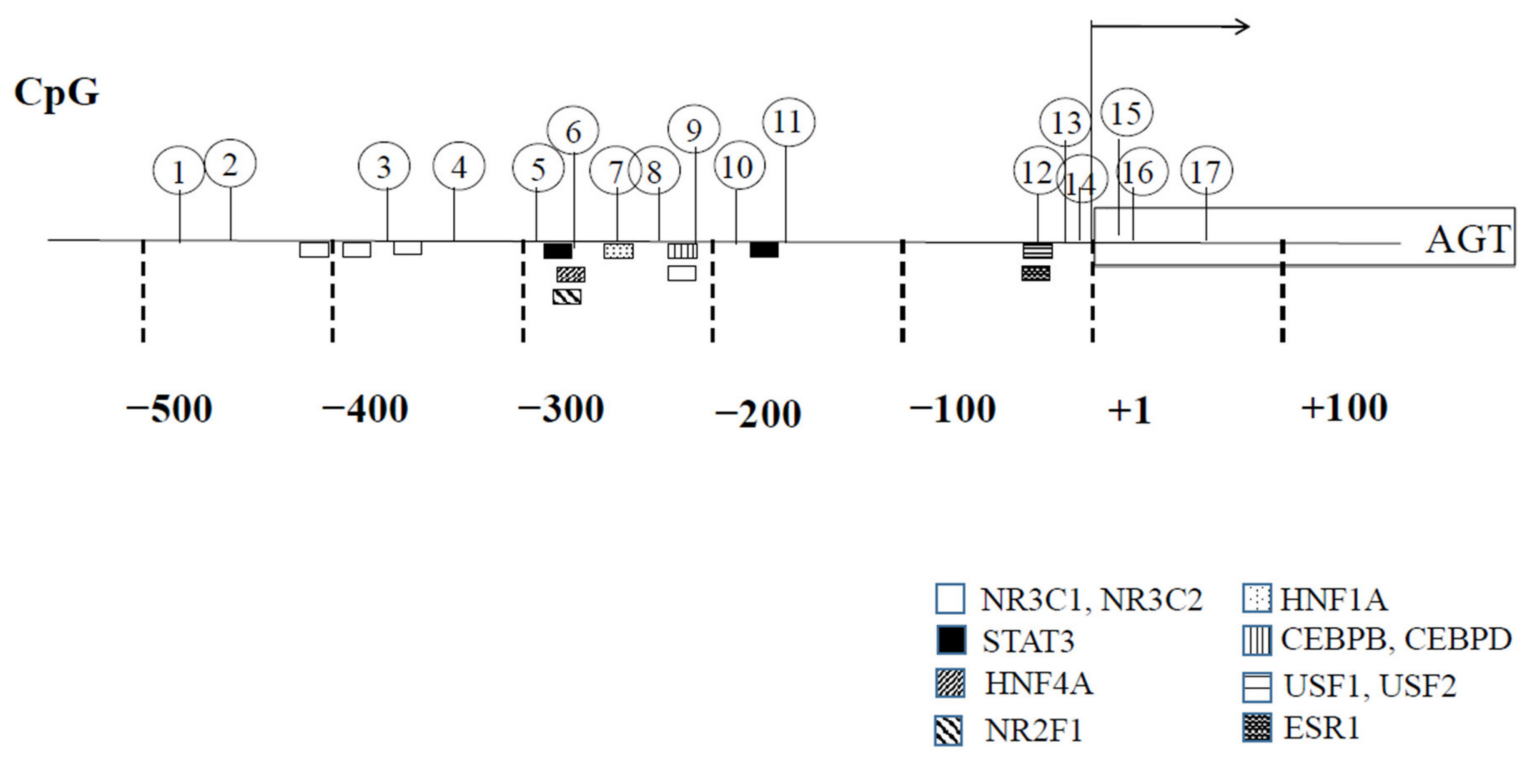

Figure 2. $\mathrm{CpG}$ dinucleotides and transcription factor-binding sites in the $A G T$ promoter. Nucleotide numbers are relative to the transcription start site. $\mathrm{CpG}$ dinucleotides from -483 to +78 are numbered from the $5^{\prime}$ to $3^{\prime}$ ends.

Overall, 17 out of the $18 \mathrm{CpG}$ dinucleotides within the human AGT promoter and its first exon $(-459$ to +66$)$ have been analyzed to determine where and how DNA demethylation and remethylation affects the interleukin 6 (IL6) stimulation. DNA demethylation was detected within $12 \mathrm{~h}$ of IL6 stimulation and reached a maximum level $24 \mathrm{~h}$ following stimulation. The first DNA demethylation event occurred around a CEBP-binding site (positions $-225 /-217$ ) as well as a transcription start site (TSS); DNA demethylation from CpG9 to CpG12 had started by that time, spreading out and stretching to CpG2 on the $5^{\prime}$-upstream side and to CpG17 on the 3'-downstream side during IL6 stimulation [36]. 
Local DNA demethylation is one of several steps in the serial recruitment of multiple transcription factors. In addition to CEBP, the signal transducer and activation transcription factor 3 (STAT3) and HNF1A are involved in the IL6-induced AGT transcription in human hepatocytes. The positive effect of STAT3 on the IL6-induced AGT transcription is mediated by its interaction with its two target DNA sites (positions $-278 /-269$ and positions $-171 /-162)$. IL6 also induces the interaction between HNF1A and the AGT promoter at positions $-247 /-236.27$. Additional transcription factors, such as STAT3 and HNF1A, are recruited when chromatin is relaxed and DNA is unmethylated, as MBD proteins have difficulty interacting with DNA without methylated CpG dinucleotides. DNA demethylation on the 5 -upstream side reaches CpG2 (position $-434 /-433$ ), suggesting that as-yet-unidentified DNA-binding transcription factors are also involved in the IL6-induced AGT transcription. Following the IL6 withdrawal, DNA remethylation concurrently progresses in a reverse manner over the next $24 \mathrm{~h}$ [36].

\section{Effect of Salt Intake on Methylation Status of the AGT Gene in the Heart}

Excess sodium intake is intimately involved in the pathogenesis of hypertension [37-41]. In large populations, significant correlations between the level of salt intake, BP, and the frequency of hypertension have been reported [42]. Several studies have shown that high salt intake reduces circulating RAAS but increased tissue RAAS in salt-sensitive hypertensive (SSH) rats $[43,44]$. Human aldosterone synthase-transgenic mice are reported to be SSH [45]. Tissue AGT is known as an important effector system for the regulation of BP. The overexpression of the AGT gene in the heart increases BP and cardiac hypertrophy and young spontaneously hypertensive rats show an elevation of tissue AGT expression [46]. High salt intake increases the cardiac AGT as well as the AT1R mRNA levels in SSH rats [29]. Treatment with MRA decreases the tissue AGT and improves cardiovascular injuries independent of the blood pressure [47].

CEBP has a pivotal role in the transcriptional regulation of the AGT gene in both humans and rats [16]. Two CEBP-binding sites (CTTGCTCCA, positions +2 to +10 ; and CTGGGAA, positions +78 to +84 ) exist in the first exon of the rat $A G T$ gene. High salt intake increases the AGT mRNA levels in the heart and demethylates the AGT promoter in SSH rats (Figure 3). Treatment with eplerenone decreases the AGT mRNA levels and methylates the AGT promoter in SSH rats. DNA demethylation occurs around the TSS and these CEBP-binding sites. These results suggest that a salt-associated stimulatory signal may recruit CEBP to its binding sites in the first exon to activate $A G T$ transcription. Treatment with MRA decreased AGT expression and increased the methylation ratio in SSH rats. This is an interesting finding since MRA influences epigenetics and causes beneficial effects to cardiovascular diseases. Based on the role of epigenesis in the development of chronic cardiovascular and metabolic diseases, it is presumed that epigenetic intervention may be an effective strategy for the treatment of these diseases. Wang et al. [48] reported the increased expression and promoter hypomethylation of the $A T 1 R$ gene in the adipose tissue of high-fat-fed spontaneously hypertensive rats were reversed by treatment with losartan. Epigenetic drugs, such as DNA methyltransferase inhibitors, were investigated in animal models of cardiovascular diseases [49]. These drugs had a deleterious effect. MRA as well as ARB may serve as a potential inducer of epigenetic modification without a deleterious complication. 

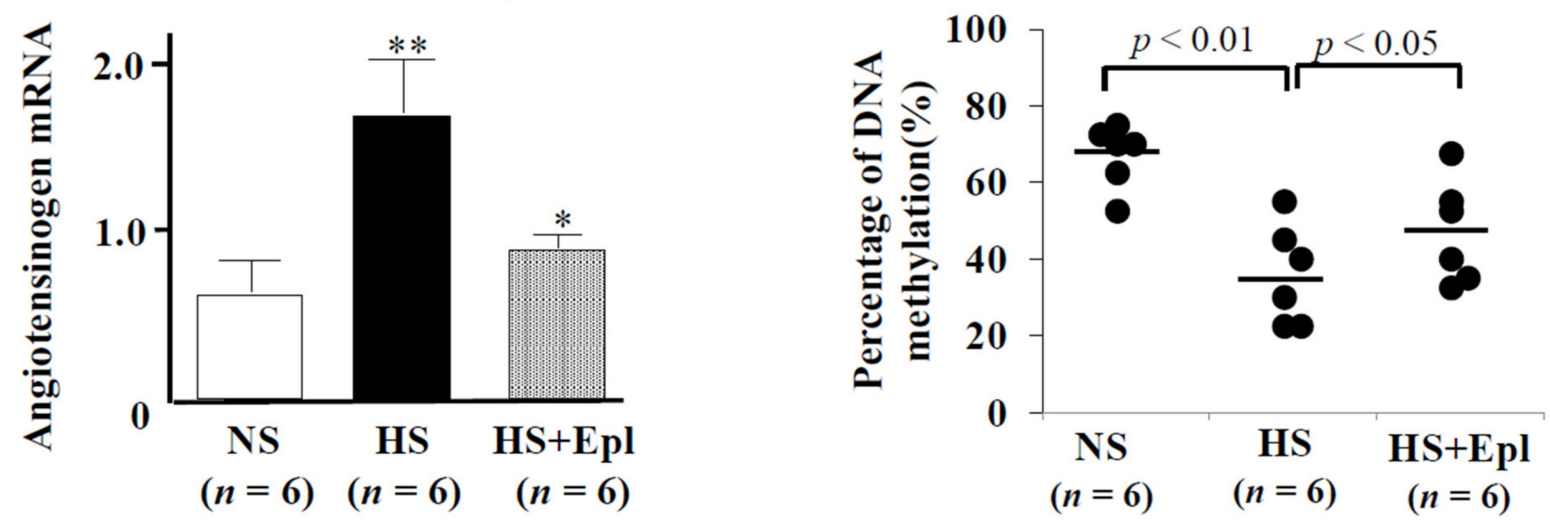

Figure 3. Effects of a high-salt diet on ATG mRNA expression and methylation of ATG in the heart of SSH rats. A low-salt diet significantly increased the ATG mRNA levels and decreased the methylation ratio of $A T G$. Treatment with eplerenone decreased the ATG mRNA levels and increased the methylation ratio of ATG. NS, normal-salt diet; HS, high-salt diet; HS + Epl. High-salt diet with treatment with eplerenone. ${ }^{* *} p<0.01$ vs. NS; ${ }^{*} p<0.05$ vs. HS.

\section{Epigenetic Modification of AGT Gene in Aldosterone-Producing Adenoma}

Primary aldosteronism (PA) has been reported with increasing frequency and accounts for $5-10 \%$ of the hypertensive population [50]. Increased prevalence of both diabetes mellitus and metabolic syndrome in patients with PA has been reported in the German Conn's Registry and in the Japan Primary Aldosteronism Study (JPAS) [51,52]. Wu et al. [53] reported that the expression of genes related to fibrosis and adipogenesis in adipose tissue was higher in patients with aldosterone-producing adenoma (APA) than in patients with non-functioning adenoma (NFA). Kalupahara et al. [12] reported that overproduction of $A G T$ from adipose tissues induces adipose inflammation, glucose intolerance, and insulin resistance.

Wang et al. [36] reported the differential effects of cortisol and aldosterone on AGT transcription in visceral adipose tissue. An excess of aldosterone in APA elicited low DNA methylation levels at all CpG dinucleotides from CpG1 to CpG13 in the AGT promoter with an accompanying upregulation of adipose tissue $A G T$ expression. However, an excess of cortisol in Cushing's adenoma did not affect the methylation status of AGT. They observed dynamic changes in DNA methylation patterns following IL6 stimulation, the first DNA demethylation event occurred around CpG9 in the AGT promoter. CpG9 exists in a DNA sequence that functions as both a GRE and a CEBP-binding site (Figure 2), implying that the activation of MRs (NR3C2) but not GRs (NR3C1) initiates chromatin remodeling along with CEBP. Members of the NR3C subfamily and many other nuclear receptor superfamily members act cooperatively with other DNA-binding transcription factors. The interaction of their target DNA sequences can integrate the hormonal response to other regulatory pathways. As is the case with the IL6-induced AGT activation, MRs and other transcription factors, such as CEBP, STAT3, and HNF1A, can bind DNA between CpG1 and CpG13 of the $A G T$ promoter and might be involved in the transcriptional activation of $A G T$ when there is an excess of aldosterone. Collectively, these results suggest that activated MRs bind DNA at positions $-225 /-217$ and have a leading role in the transcriptional activation of $A G T$, thereby recruiting other transcription factors.

\section{Contribution of DNA Methylation to Human CYP11B2 Transcription}

Aldosterone biosynthesis is under the control of potassium and angiotensin II, which increase the levels of $C Y P 11 B 2 \mathrm{mRNA}$ and lead to an increase in the activity of aldosterone synthase [54-58]. High potassium diets in rats increase the expression of CYP11B2 in the adrenal gland and aldosterone production [59].

A number of cis-acting regulatory elements have been identified in the CYP11B2 promoter: Ad1 (CRE, cAMP response element), Ad4, Ad5 and NBRE-1 (NGFI-B (nerve 
growth factor-induced clone B) response element). ATF1 or CREB1 bind to Ad1/CRE, leading to increased CYP11B2 transcription (Figure 4). Potassium as well as Ang II have the ability to activate these transcription factors $[11,60,61]$.

\section{Coactivator complex}
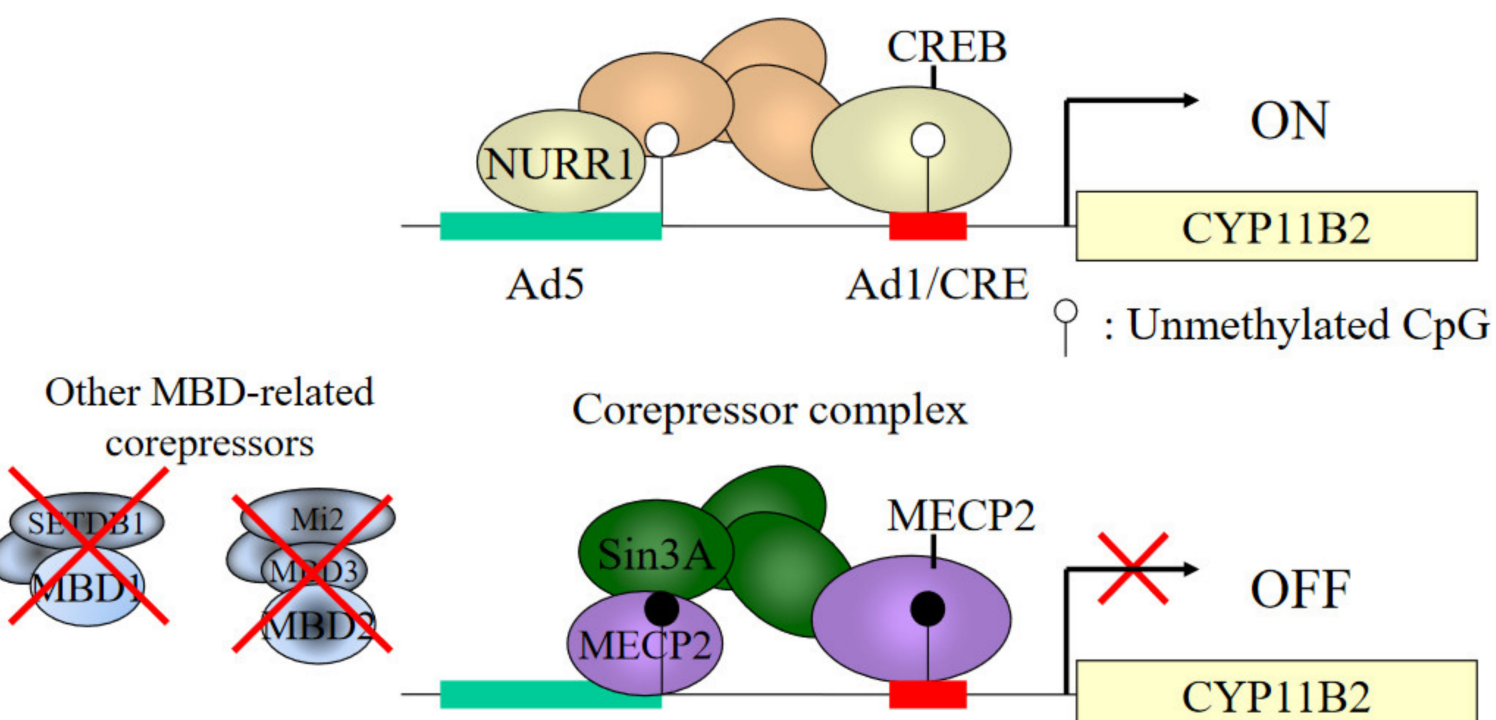

Ad5

Ad1/CRE

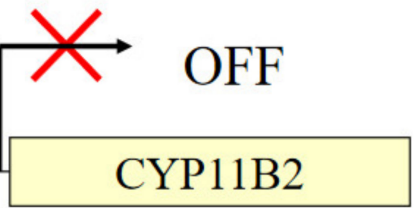

: Methylated CpG

Figure 4. Epigenetic changes of the CYP11B2 promoter region. Binding activities of coactivator complex, such as CREB and NURR1 and corepressor complex MECP2 are regulated by DNA methylation. Methylation of Cpg1 greatly decreased the CREB1 binding to Ad1. DNA methylation at CpG2 reduced the basal binding activities of NR4A1(NGF1B) and NR4A2 (NURR1) with A5. DNA methylation increased the MECP2 binding to CpG1 and CpG2. The closer relationship between other MBD-related corepressors and gene expression should be clarified.

Figure 5A shows the CpG sites of the CYP11B2 promoter region. Transcriptional activation by potassium gradually causes DNA demethylation around the CREB1- and NR4A-binding sites as well as a TSS over seven days, and its withdrawal reverses this process over the next seven days in H295R cells [62]. Although the CYP11B2 promoter is a non-CpG island promoter, each of the CREB1- and NR4A-binding sites (at positions $-71 /-64$ and positions $-129 /-114$, respectively) contains one CpG dinucleotide, and these binding sites are crucial for the basal transcription activity. In addition, two CpG dinucleotides (positions $+37 /+38,+45 /+46$ ) are located near the TSS. This CpG content of the CYP11B2 promoter offers a much greater opportunity to precisely analyze the association between DNA methylation pattern dynamics, transcription factor recruitment and chromatin relaxation than the AGT promoter. As is the case with the AGT promoter, DNA demethylation occurs upon stimulation, whereas remethylation occurs when the stimulus is removed within the CYP11B2 promoter. Changes in DNA demethylation at the NR4A -binding site and around the TSS occur two days later than those at the CREB1binding site. The NR4A-binding site, its TSS and the CREB1-binding site are remethylated to pretreatment levels 2, 4 and 7 days following the end of stimulation, respectively. These changes in DNA methylation patterns are linked to both chromatin relaxation as well as the abundance of transcription factor interactions [34]. Collectively, dynamic changes in DNA methylation following stimulation occur in relaxed chromatin regions, both where transcription factors actively interact and where transcription is initiated. 
(A)

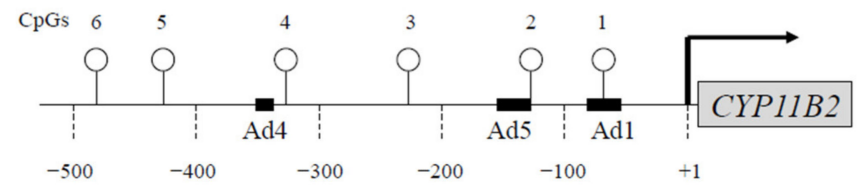

(B)
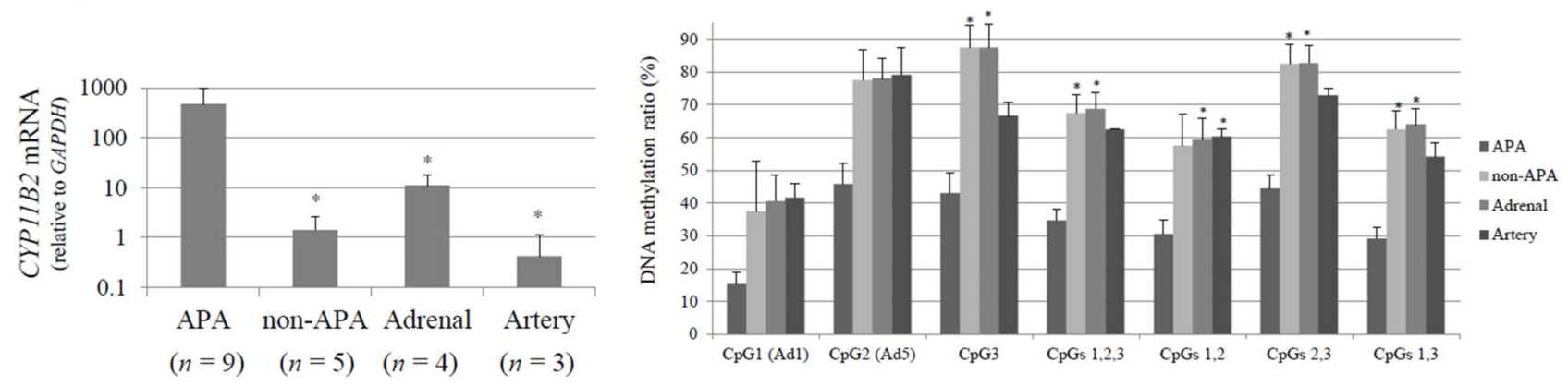

Figure 5. (A) Schema of $\mathrm{CpG}$ dinucleotides within the human CYP11B2 gene promoter. Open circle denotes CpG dinucleotides. (B) Inverse correlation between DNA methylation and CYP11B2 mRNA levels. The CYP11B2 mRNA level was significantly elevated in APA. The CPG methylation ratios of the CYP11B2 promoter was significantly decreased in APA. ${ }^{*} p<0.05$ compared to aldosterone-producing adenoma (APA) $(n=9, \mathrm{APA} ; n=5$, non-APA; $n=4$, the adrenal gland; $n=3$, the artery).

We have reported that methylation of CpG1 greatly decreased the CREB1 binding to Ad1 (21). DNA methylation at CpG2 reduced the basal binding activities of NR4A1 (NGF1B) and NR4A2 (NURR1) with Ad5 by $30 \%$ and 50\%, respectively [63]. Previous work has shown that high immunoreactivity of both NGF1B and NURR1 in the zona glomerulosa of the adrenal gland [64]. The pattern of CpG methylation and expression levels of NGF1B and NURR1 appear to have a synergistic effect on the CYP11B2 transcription in the adrenal cortex.

\section{Epigenetic Regulation of $C Y P 11 B 2$ by Angiotensin II and Salt Intake}

In the adrenal cortex, the expression of the aldosterone synthase gene, CYP11B2, is mainly controlled by the body sodium status via the RAS. Sodium restriction or Ang II infusion significantly increases CYP11B2 mRNA levels in the rat adrenal gland [65]. We reported that angiotensin II infusion in rats decreased the methylation ratio of CYP11B2 and increased gene expression in the adrenal gland [63]. A low salt diet induces hypomethylation of the rat CYP11B2 and increases the CYP11B2 mRNA levels parallel with the aldosterone synthesis. Plasma renin activity is also increased by a low salt diet. These results clearly indicate the influence of the angiotensin II in the epigenesis of CYP11B2 in the adrenal gland. Nishimoto et al. [66] reported that the rat zona glomerulosa transcriptome was changed by the dietary sodium intake, involving more than 280 differentially regulated genes. Gene ontology analysis identified three different gene groups; cell proliferation, response to a stimulus, and cholesterol/steroid metabolism. They suggested that the transcriptome changes were caused not only by the activation of the RAS but also by the neurological responses.

Aldosterone breakthrough is a phenomenon in which plasma aldosterone concentrations increase above pretreated levels after a long-term therapy with angiotensin-converting enzyme (ACE) inhibitors or Ang. II type 1 receptor blocker (ARB) [67-71]. This phenomenon may have important clinical consequences because the increased aldosterone in a high salt state may facilitate cardiovascular and renal damage in hypertensive patients [72]. The involvement of various in vivo factors, such as ACTH, electrolytes, endothelins, and Ang II type 2 receptor actions [39] have been proposed to explain this breakthrough phenomenon; however, the detailed underlying mechanism remains un- 
known. Hashimoto et al. [47] reported that the direct renin inhibitor as well as ARB caused the aldosterone breakthrough without plasma endothelin elevation. Long-term treatment with ACEI or ARB may cause CpG demethylation of CpGs 1 and 2 in the adrenal cortex, leading to aldosterone breakthrough.

\section{Epigenetic Modification of $C Y P 11 B 2$ in Aldosterone-Producing Adenoma}

Hypomethylation of CYP11B2 was detected in APAs and a negative correlation between the CYP11B2 mRNA levels and the methylation ratio was seen in our clinical samples (Figure 5B). Hypomethylation of CYP11B2 may be an important regulatory mechanism of gene expression not only in the normal adrenal gland but also in APA [73]. Howard et al. [74] reported that a CpG island in the promoter region of CYP11B2 was hypomethylated in APAs but not in blood DNA from the same patients. Yoshii et al. [75] reported the methylation rate in CpG $(-116), \mathrm{CpG}(-471)$ and CpG $(-757)$ were lowered in APAs compared with non-functioning tumors, but no significant correlation between methylation rates and mRNA levels was seen. They also demonstrated that a somatic KCNJ5 mutation did not influence the methylation rate in APAs. Nishimoto et al. [76] reported an interesting case of a patient in whom nodule development from subcapsular aldosterone-producing cell clusters (APCCs) caused hyperaldosteronism. The APCCs lie beneath the adrenal capsule and like APA, many APCCs harbor somatic gene mutations are known to increase the aldosterone production $[77,78]$. These findings suggest that APCCs may play a role in pathologic progression of PA. However, Omata et al. [79] reported that APCC are frequent in non-hypertensive Japanese adrenals, accumulate with age and frequently harbor somatic mutations (most commonly in the calcium voltage-gated channel subunit alpha1 D $(C A C N A 1 D))$. We found that the KCNJ5 mutation was detected in aldosterone-producing microadenoma and APCC in which hypomethylation of CYP11B2 was seen (unpublished data). Sun et al. [80] demonstrated specific subgroups of APCC with strikingly divergent distribution patterns of metabolites. The relationship between steroid metabolomics and the genome and epigenome of CYP11B2 in APCC should be clarified.

Medical treatment with a MRA, such as spironolactone, eplerenone or esaxerenone, is recommended to patients with PA due to bilateral adrenal disease or patients with unilateral PA who are unable or unwilling to undergo surgery [81,82]. Several papers reported cases of idiopathic hyperaldosteronism with spontaneous remission after potassium canrenoate therapy [83-85]. Yoneda et al. [86] reported a case of APA with remission after long-term spironolactone therapy. Ye et al. [87] reported that spironolactone inhibited basal and angiotensin II stimulated aldosterone synthesis in human adrenal cells. These data suggest the possibility of spironolactone acting on the methylation of CYP11B2 in both normal and aldosterone-producing adenoma cells.

\section{Gene Expression and CpG Methylation of CYP11B2 in Tissues from Cardiomyopathy}

Hypertrophic cardiomyopathy $(\mathrm{HCM})$ is the most common genetic heart disease, characterized by complex pathophysiology, heterogenous morphology, and variable clinical manifestations. The main goals of pharmacological therapy in HCM include the treatment of the left-ventricular dysfunction and HF and the control of the atrial fibrillation (AF) [88-92]. Huang et al. [93] reported that a lower risk of new AF is observed in HCM patients treated with ACE inhibitors or ARBs compared with those receiving neither of these medications. MRAs are reported to be effective for prevention of AF [94].

Aldosterone production and CYP11B2 gene expression have been shown to be upregulated in cardiac tissues during hypertrophic cardiomyopathy (HCM), and these are recognized as one of the major modifiers of the HCM phenotype [95]. We analyzed CpG methylation ratios and CYP11B2 mRNA levels using simultaneously isolated DNA and RNA from both HCM $(n=9)$ and non-HCM $(n=6)$ tissues. The CYP11B2 mRNA levels of HCM were 3.9-fold higher than those of non-HCM (Figure 6). HCM tissues were hypomethylated at $\mathrm{CpGs} 1$ and 2 compared to non-HCM tissues. The methylation ratios of CpGs 1 and 2 in HCM were approximately half of those in non-HCM (Figure 6). Inverse 
significant nonparametric correlations were observed between the CYP11B2 mRNA levels and the methylation ratios of CpGs 1 and 2 (Figure 7). These results indicated that increased CYP11B2 mRNA levels were associated with CYP11B2 demethylation in HCM and that CYP11B2 mRNA levels were inversely correlated with CYP11B2 methylation in human myocardium.
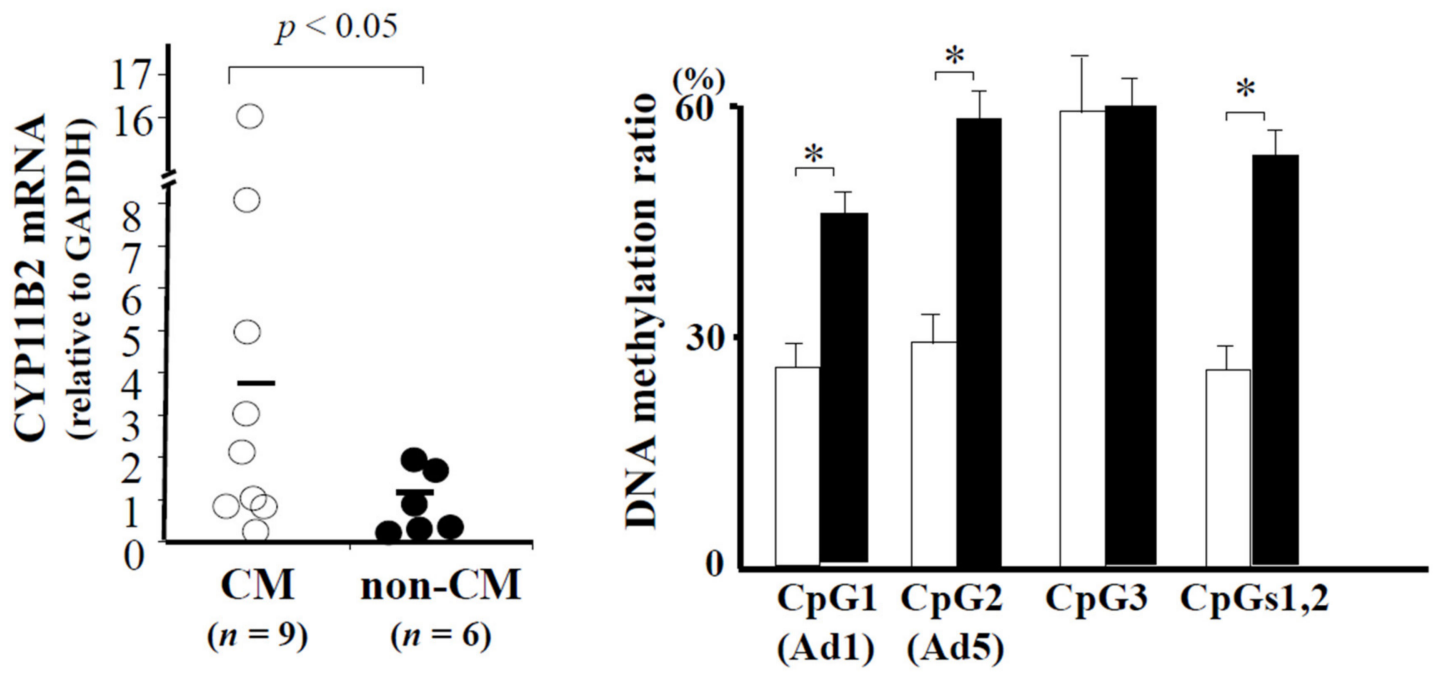

Figure 6. The CYP11B2 mRNA level was significantly increased in the heart of HCM. The CpG methylation ratios of the CYP11B2 promoter was significantly decreased in the heart of HCM. * $p<0.05$ compared to non-HCM.
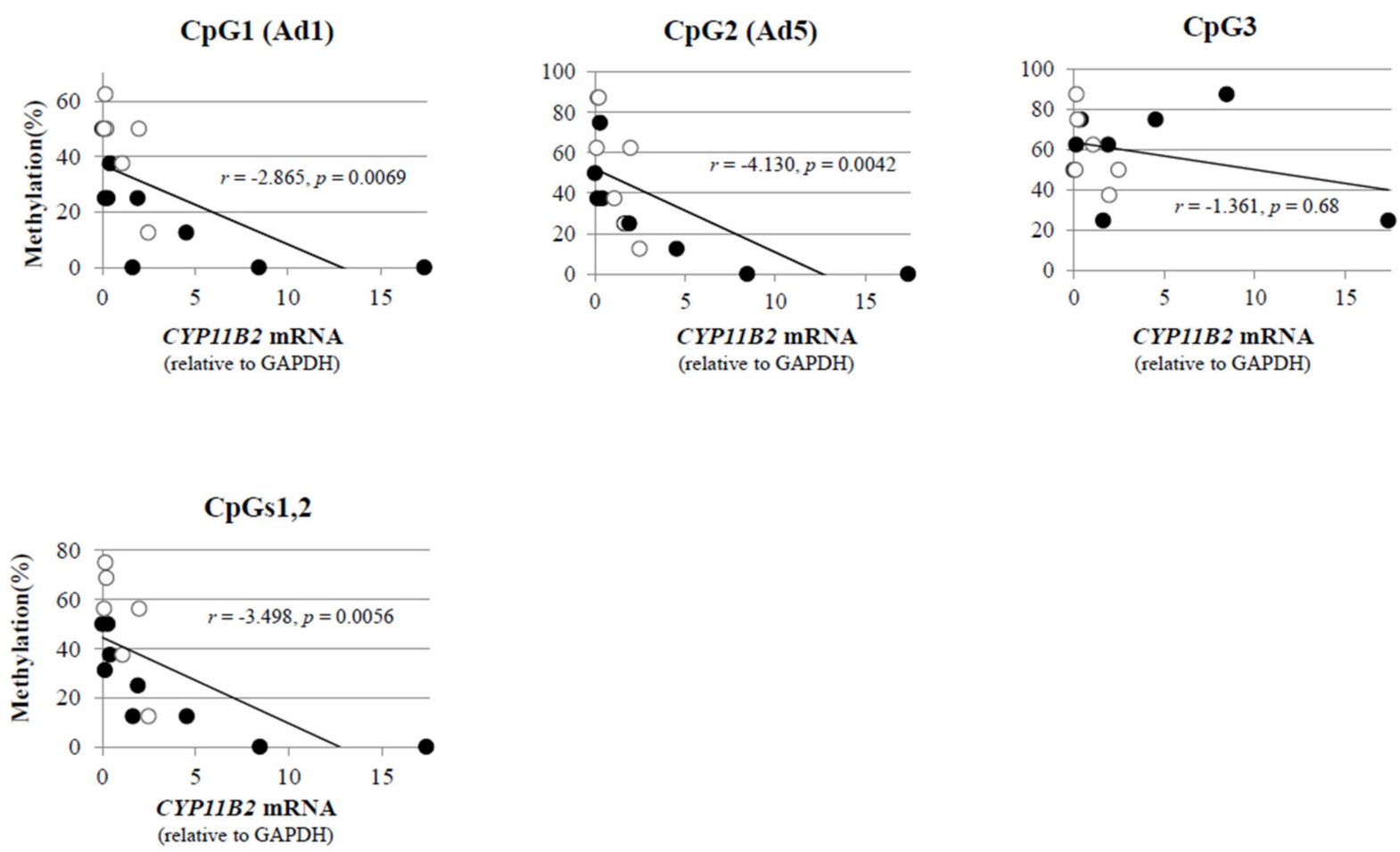

Figure 7. Inverse correlation between the CpG methylation ratios and the CYP11B2 mRNA levels. Statistically significant nonparametric inverse correlations were observed between the CpG methylation ratio and the CYP11B2 mRNA level. The CpG methylation at CpGs 1 and 2, but not CpG3, was inversely correlated with the CYP11B2 mRNA levels in the heart.

Aldosterone has direct effects on cardiac hypertrophy and fibrosis [10,96,97]. Aldosterone is locally produced in cardiovascular tissues and makes an impact via paracrine or intracrine mechanisms [98-100]. Garnier et al. [101] reported that transgenic mice overex- 
pressing CYP11B2 in the heart showed a coronary endothelium-independent dysfunction. Alesutan et al. [102] reported that the vascular CYP11B2 contributes to the stimulation of the vascular smooth muscle cells osteo-/chondrogenic transformation during hyperphosphatemia. Aldosterone synthesis in human myocardium in acute myocarditis is reported [103]. The observed increased myocardial CYP11B2 mRNA levels in patients with HCM is in accordance with the results of previous studies showing cardiovascular aldosterone synthesis. A clear association between CPG methylation and CYP11B2 gene expression in the heart is provided. We predict that DNA methylation at CpGs 1 and 2 is a key determinant of the CYP11B2 mRNA levels in the heart, and that hypomethylation of the CYP11B2 promoter causes an aberrant increase in the CYP11B2 gene expression in the pathophysiology of cardiac hypertrophy, heart failure, or cardiomyopathy. The molecular mechanisms regulating the demethylation of CpGs1 and 2 in the heart in general, and in HCM in particular, remain to be established.

Mutations in more than 30 different genes have been found to cause inherited HCM, with some been associated with a very poor prognosis [90]. However, the contribution of the causal mutations to phenotype severity can be relatively modest, with the modifier genes playing a significant role [104,105]. Identification of the modifier genes will complement the results of causative gene studies and could enhance genetic-based diagnosis, risk stratification, and implementation of preventive and therapeutic measures in patients with HCM. Epigenomic changes cause an aberrant activation of the CYP11B2 in HCM patients and they shed light on the underlying epigenomic mechanisms that enhance the severity of the cardiac phenotype.

\section{Epigenesis of Angiotensin Converting Enzyme Gene}

The angiotensin-converting enzyme (ACE) plays a central role in the RAAS, which is involved in the pathogenesis of cardiovascular diseases [106-108]. We have reported increased ACE gene expression in the heart and kidney of SSH [10,29]. Epigenetic regulation of somatic ACE by DNA methylation and histone acetylation is reported [109]. Inhibition of DNA methylation stimulates ACE mRNA expression. Mudersbach et al. [110] reported that DNA methylation determined the tumor necrosis factor (TNF)a-dependent regulation of the ACE gene transcription and thus protein expression in human endothelial cells. Lam et al. [111] reported that ACE genetic variants influenced methylation and modified the association between depression and methylation. They also reported that ACE methylation was a suitable biomarker of the cortisol and/or hypothalamic-pituitary-adrenal (HPA) axis. Activation of the HPA axis induces the glucocorticoid and mineralocorticoid receptor activity and is implicated in cardiovascular diseases [112]. Further studies are necessary to determine whether methylation of the ACE gene influences the glucocorticoid or mineralocorticoid receptor activity.

\section{Conclusions}

The presence of local RAAS in cardiovascular and adipose tissues and their influence in cardiovascular and metabolic diseases are described. Gene expression of AGT and CYP11B2 is reversibly regulated by an epigenetic modification. Both a high salt diet and an excess aldosterone production influence the methylation status of the AGT and CYP11B2 genes. The relationship between the epigenetic regulation of RAAS by environmental factors or hormone excess and the pathogenesis of cardiovascular diseases should be further clarified.

Funding: This research was funded by the Japan Promotion of Science, grant number 21790889, 1 April 2015 and the Ministry of Health, Labor and Welfare of Japan, 1 April 2017.

Institutional Review Board Statement: The study was approved by the Institutional Review Boards of Kanazawa University Graduate School of Medical Science, approved number 306-10, 1 April 2015.

Informed Consent Statement: The purpose of the study was explained, and written informed consent was obtained from all study participants to publish this paper. 
Data Availability Statement: Not applicable.

Conflicts of Interest: The authors declare no conflict of interest.

\section{Abbreviations}

ACE angiotensin converting enzyme

Ad cis-acting element

AGT angiotensinogen

AMP adenylic acid

Ang II angiotensin II;

ARB AT1R blocker;

APA aldosterone-producing adenoma

APCC aldosterone-producing cell cluster

ATF activating transcription factor

AT1R type2 angiotensin II receptor

BP blood pressure

CACNA1D Calcium Voltage-Gated Channel Subunit Alpha1 D

CEBP CCAAT enhancer binding protein

CREB cyclic AMP responsive element binding protein

CYP11B2 aldosterone synthase

Epl eprelenone

ESR estrogen receptor

GR glucocorticoid receptor

GRE GR element

HCM hypertrophic cardiomyopathy

HF heart failure

HNF1A hepatocyte nuclear factor1 homeobox A

HPA hypothalamic-pituitary-adrenal

IL 6 interleukin 6

JPAS Japan primary aldosteronism study

KCNJ potassium inwardly rectifying channel J subfamily J

MBD methyl-CpG-binding domain

MECP methyl-CpG-binding protein

Mi2 chromodomain-helicase-DNA-binding protein Mi-2 homolog

MR mineralocorticoid receptor

MRA mineralocorticoid receptor antagonist

NGFI-B nerve growth factor-induced clone B

NBRE-1 NGFI-B response element

NFA non-functioning adenoma

NR4A nuclear receptor 4 group A

NS normal salt

NURR1 nuclear receptor-related factor 1

PA primary aldosteronism

RAAS renin-angiotensin-aldosterone system

rEF reduced left-ventricular ejection fraction

ReR renin receptor

SETDB histone-lysine N-methyltransferase

Sin3A SIN3 transcription regulator family member A

SSH salt-sensitive hypertension

STAT signal transducer and activation transcription factor

TNF tumor necrosis factor

TSS transcription start site

USF upstream stimulatory factor 


\section{References}

1. Paz Ocaranza, M.; Riquelme, J.A.; García, L.; Jalil, J.E.; Chiong, M.; Santos, R.A.S.; Lavandero, S. Counter-regulatory reninangiotensin system in cardiovascular disease. Nat. Rev. Cardiol. 2020, 17, 116-129. [CrossRef] [PubMed]

2. Azushima, K.; Morisawa, N.; Tamura, K.; Nishiyama, A. Recent research advances in renin-angiotensin-aldosterone system receptors. Curr. Hypertens. Rep. 2020, 22. [CrossRef]

3. Ames, M.K.; Atkins, C.E.; Pitt, B.J. The renin-angiotensin-aldosterone system and its suppression. Vet. Intern. Med. 2019, 33, 363-382. [CrossRef]

4. $\quad$ Briet, M.; Barhoumi, T.; Oneeb, M.; Mian, R.; Coelho, S.C.; Ouerd, S.; Rautureau, Y.; Coffman, T.M.; Paradis, P.; Schiffrin, E.L. Aldosterone-induced vascular remodeling and endothelial dysfunction require functional angiotensin type 1a receptors. Hypertension 2016, 67, 897-905. [CrossRef]

5. Ferrario, C.M.; Mullick, A.E. Renin angiotensin aldosterone inhibition in the treatment of cardiovascular disease. Pharmacol. Res. 2017, 125, 57-71. [CrossRef] [PubMed]

6. Stoll, D.; Yokota, R.; Sanches Aragão, D.; Casarini, D.E. Both aldosterone and spironolactone can modulate the intracellular ACE/ANG II/AT1 and ACE2/ANG (1-7)/MAS receptor axes in human mesangial cells. Physiol. Rep. 2019, 11, e14105. [CrossRef]

7. Miller, A.J.; Arnold, A.C. The renin-angiotensin system in cardiovascular autonomic control: Recent developments and clinical implications. Clin. Auton. Res. 2019, 29, 231-243. [CrossRef] [PubMed]

8. Mochel, J.P.; Teng, C.H.; Peyrou, M.; Giraudel, J.; Danhof, M.; Rigel, D.F. Sacubitril/valsartan (LCZ696) significantly reduces aldosterone and increases cGMP circulating levels in a canine model of RAAS activation. Eur. J. Pharm. Sci. 2019, 128, 103-111. [CrossRef]

9. Inui, Y.; Mochida, H.; Yamairi, F.; Okada, M.; Ishida, J.; Fukamizu, A.; Arakawa, K. Effects of aging and uninephrectomy on renal changes in Tsukuba hypertensive mice. Biomed. Rep. 2013, 1, 359-364. [CrossRef]

10. Zhu, A.; Yoneda, T.; Demura, M.; Karashima, S.; Usukura, M.; Yamagishi, M.; Takeda, Y. Effect of mineralocorticoid receptor blockade on the renal renin-angiotensin system in Dahl salt-sensitive hypertensive rats. J. Hypertens. 2009, 27, 800-805. [CrossRef] [PubMed]

11. Massiera, F.; Bloch-Faure, M.; Ceiler, D.; Murakami, K.; Fukamizu, A.; Gasc, J.M.; Quignard-Boulange, A.; Negrel, R.; Ailhaud, G.; Seydoux, J.; et al. Adipose angiotensinogen is involved in adipose tissue growth and blood pressure regulation. FASEB J. 2001, 15, 2727-2729. [CrossRef] [PubMed]

12. Kalupahana, N.S.; Massiera, F.; Quignard-Boulange, A.; Ailhaud, G.; Voy, B.H.; Wasserman, D.H.; Moustaid-Moussa, N. Overproduction of angiotensinogen from adipose tissue induces adipose inflammation, glucose Intolerance, and insulin resistance. Obesity 2012, 20, 48-56. [CrossRef]

13. Yasue, S.; Masuzaki, H.; Okada, S.; Ishii, T.; Kozuka, C.; Tanaka, T.; Fujikura, J.; Ebihara, K.; Hosoda, K.; Katsurada, A.; et al Adipose tissue-specific regulation of angiotensinogen in obese humans and mice: Impact of nutritional status and adipocyte hypertrophy. Am. J. Hypertens. 2010, 23, 425-431. [CrossRef] [PubMed]

14. Davel, A.P.; Jaffe, I.Z.; Tostes, R.C.; Jaisser, F.; Chantemèle, E.J.B. New roles of aldosterone and mineralocorticoid receptors in cardiovascular disease: Translational and sex-specific effects. Am. J. Physiol. Heart Circ. Physiol. 2018, 315, H989-H999. [CrossRef]

15. Takeda, Y.; Yoneda, T.; Demura, M.; Usukura, M.; Mabuchi, H. Calcineurin inhibition attenuates mineralocorticoid-induced cardiac hypertrophy. Circulation 2002, 105, 677-679. [CrossRef] [PubMed]

16. Rico-Mesa, J.S.; White, A.; Ahmadian-Tehrani, A.; Anderson, A.S. Mineralocorticoid receptor antagonists: A comprehensive review of finerenone. Curr. Cardiol. Rep. 2020, 22, 140. [CrossRef] [PubMed]

17. Capelli, I.; Gasperoni, L.; Ruggeri, M.; Donati, G.; Baraldi, O.; Sorrenti, G.; Caletti, M.T.; Aiello, V.; Cianciolo, G.; La Manna, G. New mineralocorticoid receptor antagonists: Update on their use in chronic kidney disease and heart failure. J. Nephrol. 2020, 33, 37-48. [CrossRef]

18. Ohno, Y.; Sone, M.; Inagaki, N.; Yamasaki, T.; Ogawa, O.; Takeda, Y.; Kurihara, I.; Itoh, H.; Umakoshi, H.; Tsuiki, M.; et al. Prevalence of cardiovascular disease and its risk factors in primary aldosteronism: A multicenter study in Japan. Hypertension 2018, 71, 530-537. [CrossRef]

19. Zennaro, M.C.; Boulkroun, S.; Fernandes-Rosa, F.L. Pathogenesis and treatment of primary aldosteronism. Nat. Rev. Endocrinol. 2020, 16, 578-589. [CrossRef]

20. Vaidya, A.; Carey, R.M. Evolution of the primary aldosteronism syndrome: Updating the approach. J. Clin. Endocrinol. Metab. 2020, 105, 3771-3783. [CrossRef]

21. Yang, Y.; Reincke, M.; Williams, T.A. Prevalence, diagnosis and outcomes of treatment for primary aldosteronism. Best Pract. Res. Clin. Endocrinol. Metab. 2020, 34, 101365. [CrossRef]

22. Pillai, P.R.; Griffith, M.; Schwarcz, M.D.; Weiss, I.A. Primary aldosteronism: Cardiovascular risk, diagnosis, and management. Cardiol. Rev. 2020, 28, 84-91. [CrossRef]

23. Morimoto, S.; Ichihara, A. Management of primary aldosteronism and mineralocorticoid receptor-associated hypertension. Hypertens. Res. 2020, 43, 744-753. [CrossRef] [PubMed]

24. Kolkhof, P.; Bärfacker, L. 30 Years of the mineralocorticoid receptor: Mineralocorticoid receptor antagonists: 60 years of research and development. J. Endocrinol. 2017, 234, T125-T140. [CrossRef] [PubMed] 
25. Kjeldsen, S.E.; von Lueder, T.G.; Smiseth, O.A.; Wachtell, K.; Mistry, N.; Westheim, A.S.; Hopper, I.; Julius, S.; Pitt, B.; Reid, C.M.; et al. Medical therapies for heart failure with preserved ejection fraction. Hypertension 2020, 75, 23-32. [CrossRef] [PubMed]

26. Pandey, A.; Garg, S.; Matulevicius, S.A.; Shah, A.M.; Garg, J.; Drazner, M.H.; Amin, A.; Berry, J.D.; Marwick, T.H.; Marso, S.P.; et al. Effect of mineralocorticoid receptor antagonists on cardiac structure and function in patients with diastolic dysfunction and heart failure with preserved ejection fraction: A meta-analysis and systematic review. J. Am. Heart Assoc. 2015, 4, e002137. [CrossRef] [PubMed]

27. Dragasevic, N.; Jakovljevic, V.; Zivkovic, V.; Draginic, N.; Andjic, M.; Bolevich, S.; Jovic, S. The role of aldosterone inhibitors in cardiac ischemia-reperfusion injury. Can. J. Physiol. Pharmacol. 2021, 99, 18-29. [CrossRef]

28. Pradhan, A.; Vohra, S.; Sethi, R. Eplerenone: The multifaceted drug in cardiovascular pharmacology. J. Pharm. Bioallied. Sci. 2020, 12, 381-390. [CrossRef]

29. Takeda, Y.; Zhu, A.; Yoneda, T.; Usukura, M.; Takata, H.; Yamagishi, M. Effects of aldosterone and angiotensin II receptor blockade on cardiac angiotensinogen and angiotensin-converting enzyme 2 expression in Dahl salt-sensitive hypertensive rats. Am. $J$. Hypertens. 2007, 10, 1119-1124. [CrossRef]

30. Rocha, R.; Rudolph, A.E.; Frierdich, G.E.; Nachowiak, D.A.; Kekec, B.K.; Blomme, E.A.; McMahon, E.G.; Delyani, J.A. Aldosterone induces a vascular inflammatory phenotype in the rat heart. Am. J. Physiol. Heart Circ. Physiol. 2002, 283, H1802-H1810. [CrossRef]

31. Salameh, Y.; Bejaoui, Y.; El Hajj, N. DNA methylation biomarkers in aging and age-related diseases. Front. Genet. 2020, 11, 171. [CrossRef]

32. Köhler, F.; Rodríguez-Paredes, M. DNA methylation in epidermal differentiation, aging, and cancer. J. Investig. Dermatol. 2020, 140, 38-47. [CrossRef] [PubMed]

33. Liang, M. Epigenetic mechanisms and hypertension. Hypertension 2018, 72, 1244-1254. [CrossRef] [PubMed]

34. Demura, M.; Demura, Y.; Takeda, Y.; Saijoh, K. Dynamic regulation of the angiotensinogen gene by DNA methylation, which is influenced by various stimuli experienced in daily life. Hypertens. Res. 2015, 38, 519-527. [CrossRef]

35. Parry, A.; Rulands, S.; Reik, W. Active turnover of DNA methylation during cell fate decisions. Nat. Rev. Genet. 2021, 22, 59-66. [CrossRef]

36. Wang, F.; Demura, M.; Cheng, Y.; Zhu, A.; Karashima, S.; Yoneda, T.; Demura, Y.; Maeda, Y.; Namiki, M.; Ono, K.; et al. Dynamic CCAAT/enhancer binding protein-associated changes of DNA methylation in the angiotensinogen gene. Hypertension 2014, 63, 281-288. [CrossRef]

37. Faulkner, J.L.; de Chantemèle, E.J.B. Female sex, a major risk factor for salt-sensitive hypertension. Curr. Hypertens. Rep. 2020, 22, 99. [CrossRef] [PubMed]

38. Khan, M.S.; Jones, D.W.; Butler, J. Salt, no salt, or less salt for patients with heart failure? Am. J. Med. 2020, 133, 32-38. [CrossRef] [PubMed]

39. Bhat, S.; Marklund, M.; Henry, M.E.; Appel, L.J.; Croft, K.D.; Neal, B.; Wu, J.H. A systematic review of the sources of dietary salt around the world. Adv. Nutr. 2020, 11, 677-686. [CrossRef]

40. Huang, L.; Trieu, K.; Yoshimura, S.; Neal, B.; Woodward, M.; Campbell, N.R.C.; Li, Q.; Lackland, D.T.; Leung, A.A.; Anderson, C.A.M.; et al. Effect of dose and duration of reduction in dietary sodium on blood pressure levels: Systematic review and meta-analysis of randomised trials. BMJ 2020, 368, m315. [CrossRef]

41. Grillo, A.; Salvi, L.; Coruzzi, P.; Salvi, P.; Parati, G. Sodium intake and hypertension. Nutrients 2019, 11, 1970. [CrossRef]

42. He, F.J.; Tan, M.; Ma, Y.; MacGregor, G.A. Salt reduction to prevent hypertension and cardiovascular disease: JACC state-of-the-art review. J. Am. Coll. Cardiol. 2020, 75, 632-647. [CrossRef] [PubMed]

43. Nishiyama, A.; Kobori, H. Independent regulation of renin-angiotensin-aldosterone system in the kidney. Clin. Exp. Nephrol. 2018, 22, 1231-1239. [CrossRef] [PubMed]

44. Faulkner, J.L.; Harwood, D.; Bender, L.; Shrestha, L.; Brands, M.W.; Morwitzer, J.; Kennard, S.; Antonova, G.; Chantemèle, E.J.B. Lack of suppression of aldosterone production leads to salt sensitive hypertension in female but not male Balb/C mice. Hypertension 2018, 72, 1397-1406. [CrossRef] [PubMed]

45. Gu, H.; Ma, Z.; Wang, J.; Zhu, T.; Du, N.; Shatara, A.; Yi, X.; Kowala, M.C.; Du, Y. Salt-dependent blood pressure in human aldosterone synthase-transgenic mice. Sci. Rep. 2017, 7, 492. [CrossRef]

46. Pellieux, C.; Montessuit, C.; Papageorgiou, I.; Pedrazzini, T.; Lerch, R. Differential effects of high-fat diet on myocardial lipid metabolism in failing and nonfailing hearts with angiotensin II-mediated cardiac remodeling in mice. Am. J. Physiol. Heart Circ. Physiol. 2012, 302, H1795-H1805. [CrossRef]

47. Hashimoto, A.; Takeda, Y.; Karashima, S.; Kometani, M.; Aono, D.; Higashikata, T.; Konishi, S.; Yoneda, T.; Takeda, Y. Impact of mineralocorticoid receptor blockade with direct renin inhibition in angiotensin II-dependent hypertensive mice. Hypertens. Res. 2020, 43, 1099-1104. [CrossRef]

48. Wang, T.; Lian, G.; Cai, X.; Lin, Z.; Xie, L. Effect of prehypertensive losartan therapy on AT1R and ATRAP methylation of adipose tissue in the later life of high-fat-fed spontaneously hypertensive rats. Mol. Med. Rep. 2018, 17, 1753-1761. [CrossRef] [PubMed]

49. Xiao, D.; Dasgupta, C.; Chen, M.; Zhang, K.; Buchholz, J.; Xu, Z.; Zang, L. Inhibition of DNA methylation reverses norepinephrineinduced cardiac hypertrophy in rats. Cardiovasc. Res. 2014, 101, 373-382. [CrossRef] 
50. Vaidya, A.; Mulatero, P.; Baudrand, R.; Adler, G.K. The expanding spectrum of primary aldosteronism: Implications for diagnosis, pathogenesis, and treatment. Endocr. Rev. 2018, 39, 1057-1088. [CrossRef] [PubMed]

51. Hanslik, G.; Wallaschofski, H.; Dietz, A.; Riester, A.; Reincke, M.; Allolio, B.; Lang, K.; Quack, I.; Rump, L.C.; Willenberg, H.S.; et al. Increased prevalence of diabetes mellitus and the metabolic syndrome in patients with primary aldosteronism of the German Conn's Registry. Eur. J. Endocrinol. 2015, 173, 665-675. [CrossRef]

52. Akehi, Y.; Yanase, T.; Motonaga, R.; Umakoshi, H.; Tsuiki, M.; Takeda, Y.; Yoneda, T.; Kurihara, I.; Itoh, H.; Katabami, T.; et al. High prevalence of diabetes in patients with primary aldosteronism (PA) associated withsubclinical hypercortisolism and prediabetes more prevalent in bilateral than unilateral PA: A large, multicenter cohort study in Japan. Diabetes Care. 2019, 42, 938-945. [CrossRef]

53. Wu, C.; Zhang, H.; Zhang, J.; Zhang, H.; Zeng, Y.; Fang, S.; Li, P.; Zhang, Y.; Lin, X.; Wang, L.; et al. Increased oxidative stress, inflammation and fibrosis in perirenal adipose tissue of patients with aldosterone-producing adenoma. Adipocyte 2019, 8, 347-356. [CrossRef]

54. Takeda, Y.; Miyamori, I.; Yoneda, T.; Hatakeyama, H.; Inaba, S.; Furukawa, K.; Mabuchi, H.; Takeda, R. Regulation of aldosterone synthase in human vascular endothelial cells by angiotensin II and adrenocorticotropin. J. Clin. Endocrinol. Metab. 1996, 81, 2797-2800.

55. Guagliardo, N.A.; Klein, P.M.; Gancayco, C.A.; Lu, A.; Leng, S.; Makarem, R.R.; Cho, C.; Rusin, C.G.; Breault, D.T.; Barrett, P.Q.; et al. Angiotensin II induces coordinated calcium bursts in aldosterone-producing adrenal rosettes. Nat. Commun. 2020, 11, 1679. [CrossRef] [PubMed]

56. Ali, Y.; Dohi, K.; Okamoto, R.; Katayama, K.; Ito, M. Novel molecular mechanisms in the inhibition of adrenal aldosterone synthesis: Action of tolvaptan via vasopressin $V_{2}$ receptor-independent pathway. Br. J. Pharmacol. 2019, 176, 1315-1327. [CrossRef]

57. Vanderriele, P.E.; Caroccia, B.; Seccia, T.M.; Piazza, M.; Lenzini, L.; Torresan, F.; Iacobone, M.; Unger, T.; Rossi, G.P. The angiotensin type 2 receptor in the human adrenocortical zona glomerulosa and in aldosterone-producing adenoma: Low expression and no functional role. Clin. Sci. 2018, 132, 627-640. [CrossRef] [PubMed]

58. Hardege, I.; Long, L.; Al Maskari, R.; Figg, N.; O'Shaughnessy, K.M. Targeted disruption of the Kcnj5 gene in the female mouse lowers aldosterone levels. Clin. Sci. 2018, 132, 145-156. [CrossRef]

59. Peters, B.; Teubner, P.; Clausmeyer, S.; Puschner, T.; Maser-Gluth, C.; Wrede, H.J.; Kränzlin, B.; Peters, J. StAR expression and the long-term aldosterone response to high-potassium diet in Wistar-Kyoto and spontaneously hypertensive rats. Am. J. Physiol. Endocrinol. Metab. 2007, 292, E16-E23. [CrossRef]

60. Demura, M.; Wang, F.; Yoneda, T.; Karashima, S.; Mori, S.; Oe, M.; Kometani, M.; Sawamura, T.; Cheng, Y.; Maeda, Y.; et al Multiple noncoding exons 1 of nuclear receptors NR4A family (nerve growth factor-induced clone B, Nur-related factor 1 and neuron-derived orphan receptor 1) and NR5A1 (steroidogenic factor 1) in human cardiovascular and adrenal tissues. J. Hypertens. 2011, 29, 1185-1195. [CrossRef] [PubMed]

61. Dierks, A.D.; Urs, D.; Lichtenauer, U.D.; Sackmann, S.; Spyroglou, A.; Shapiro, I.; Geyer, M.; Manonopoulou, J.; Reincke, M.; Hantel, C.; et al. Identification of adrenal genes regulated in a potassium-dependent manner. J. Mol. Endocrinol. 2010, 45, 193-206. [CrossRef] [PubMed]

62. Takeda, Y.; Demura, M.; Wang, F.; Karashima, S.; Yoneda, T.; Kometani, M.; Aomo, D.; Hashimoto, A.; Horike, S.; Meguro-Horike, M. Effect of potassium on DNA methylation of aldosterone synthase gene. J. Hypertens. 2021. [CrossRef] [PubMed]

63. Takeda, Y.; Demura, M.; Wang, F.; Karashima, S.; Yoneda, T.; Kometani, M.; Hashimoto, A.; Aono, D.; Horike, S.; Meguro-Horike, M.; et al. Epigenetic regulation of aldosterone synthase gene by sodium and angiotensin I.I. J. Am. Heart Assoc. 2018, 7, e008281. [CrossRef] [PubMed]

64. Lu, L.; Suzuki, T.; Yoshikawa, Y.; Murakami, O.; Miki, Y.; Moriya, T.; Bassett, M.H.; Rainey, W.E.; Hayashi, Y.; Sasano, H. Nur-related factor 1 and nerve growth factor-induced clone B in human adrenal cortex and its disorders. J. Clin. Endocrinol. Metab. 2004, 89, 4113-4118. [CrossRef] [PubMed]

65. Nogueira, E.F.; Vargas, C.A.; Otis, M.; Gallo-Payet, N.G.; Bollag, W.B.; Rainey, W.E. Angiotensin-II acute regulation of rapid response genes in human, bovine, and rat adrenocortical cells. J. Mol. Endocrinol. 2007, 39, 365-374. [CrossRef]

66. Nishimoto, K.; Harris, R.B.S.; Rainey, W.E.; Seki, T. Sodium deficiency regulates rat adrenal zona glomerulosa gene expression. Endocrinology 2014, 155, 1363-1372. [CrossRef] [PubMed]

67. Vergaro, G.; Passino, C.; Emdin, M.J. No aldosterone breakthrough with the neprilysin inhibitor sacubitril. Am. Coll. Cardiol. 2019, 73, 3037-3038. [CrossRef]

68. Narayan., H.; Webb, D.J. New evidence supporting the use of mineralocorticoid receptor blockers in drug-resistant hypertension. Curr. Hypertens. Rep. 2016, 5, 34. [CrossRef]

69. Goenka, L.; Padmanaban, R.; George, M. The ascent of mineralocorticoid receptor antagonists in diabetic nephropathy. Curr. Clin. Pharmacol. 2019, 14, 78-83. [CrossRef] [PubMed]

70. Bomback, A.S.; Klemmer, P.J. The incidence and implications of aldosterone breakthrough. Nephrology 2007, 3, 486-492. [CrossRef]

71. Waanders, F.; de Vries, L.V.; van Goor, H.; Hillebrands, J.L.; Laverman, G.D.; Bakker, S.J.; Navis, G. Aldosterone, from (patho)physiology to treatment in cardiovascular and renal damage. Curr. Vasc. Pharmacol. 2011, 9, 594-605. [CrossRef] [PubMed]

72. Kawarazaki, W.; Fujita, T. The role of aldosterone on obesity-related hypertension. Am. J. Hypertens. 2016, 29, 415-423. [CrossRef] 
73. Di Dalmazi, G.; Morandi, L.; Rubin, B.; Pilon, C.; Asioli, S.; Vicennati, V.; De Leo, A.; Ambrosi, F.; Santini, D.; Pagotto, U.; et al. DNA methylation of steroidogenic enzymes in benign adrenocortical tumors: New insights in aldosterone-producing adenomas. J. Clin. Endocrinol. Metab. 2020, 105, dgaa585. [CrossRef] [PubMed]

74. Howard, B.; Wang, Y.; Xekouki, P.; Faucz, F.R.; Jain, M.; Zhang, L.; Meltzer, P.G.; Stratakis, C.A.; Kebebew, E. Integrated analysis of genome-wide methylation and gene expression shows epigenetic regulation of CYP11B2 in aldosteronomas. J. Clin. Endocrinol. Metab. 2014, 99, E536-E543. [CrossRef]

75. Yoshii, Y.; Oki, K.; Gomez-Sanchez, C.E.; Ohno, H.; Itcho, K.; Kobuke, K.; Yoneda, M. Hypomethylation of CYP11B2 in aldosterone-producing adenoma. Hypertension 2016, 68, 1432-1437. [CrossRef]

76. Nishimoto, K.; Seki, T.; Kurihara, I.; Yokota, K.; Omura, M.; Nishikawa, T.; Shibata, H.; Kosaka, T.; Oya, M.; Suematsu, M.; et al. Case report: Nodule development from subcapsular aldosterone producing cell clusters causes hyperaldosteronism. J. Clin. Endocrinol. Metab. 2016, 101, 6-9. [CrossRef] [PubMed]

77. Lim, J.S.; Rainey, W.E. The potential role of aldosterone-producing cell clusters in adrenal disease. Horm. Metab. Res. 2020, 52, 427-434. [CrossRef]

78. De Sousa, K.; Boulkroun, S.; Baron, S.; Nanba, K.; Wack, M.; Rainey, W.E.; Rocha, A.; Giscos-Douriez, I.; Meatchi, T.; Amar, L.; et al. Genetic, cellular, and molecular heterogeneity in adrenals with aldosterone-producing adenoma. Hypertension 2020, 75, 1034-1044. [CrossRef]

79. Omata, K.; Anand, S.K.; Hovelson, D.H.; Liu, C.J.; Yamazaki, Y.; Nakamura, Y.; Ito, S.; Satoh, F.; Sasano, H.; Rainey, W.E.; et al. Aldosterone-producing cell clusters frequently harbor somatic mutations and accumulate with age in mormal adrenals. J. Endocr. Soc. 2017, 1, 787-799. [CrossRef]

80. Sun, N.; Meyer, L.S.; Feuchtinger, A.; Kunzke, T.; Knösel, T.; Reincke, M.; Walch, A.; Williams, T.A. Mass spectrometry imaging establishes 2 distinct metabolic phenotypes of aldosterone-producing cell clusters in primary aldosteronism. Hypertension 2020, 75, 634-644. [CrossRef] [PubMed]

81. Rossi, G.P. Primary aldosteronism: JACC state-of-the-art review. J. Am. Coll. Cardiol. 2019, 74, 2799-2811. [CrossRef]

82. Sueta, D.; Yamamoto, E.; Tsujita, K. Mineralocorticoid receptor blockers: Novel selective nonsteroidal mineralocorticoid receptor antagonists. Curr. Hypertens. Rep. 2020, 22, 21. [CrossRef] [PubMed]

83. Armanini, D.; Fiore, C.; Pellati, D. Spontaneous resolution of idiopathic aldosteronism after long-term treatment with potassium canrenoate. Hypertension 2007, 50, e69-e70. [CrossRef] [PubMed]

84. Fischer, E.; Beuschlein, F.; Degenhart, C.; Jung, P.; Bidlingmaier, M.; Reincke, M. Spontaneous remission of idiopathic aldosteronism after long-term treatment with spironolactone: Results from the German Conn's Registry. Clin. Endocrinol. 2012, 76, 473-477. [CrossRef] [PubMed]

85. Lucatello, B.; Benso, A.; Tabaro, I.; Capello, E.; Caprino, M.P.; Marafetti, L.; Rossato, D.; Oleandri, S.E.; Ghigo, E.; Maccario, M. Long-term re-evaluation of primary aldosteronism after medical treatment reveals high proportion of normal mineralocorticoid secretion. Eur. J. Endocrinol. 2013, 168, 525-532. [CrossRef]

86. Yoneda, T.; Demura, M.; Takata, H.; Kometani, M.; Karashima, S.; Yamagishi, M.; Takeda, Y. Unilateral primary aldosteronism with spontaneous remission after long-term spironolactone therapy. J. Clin. Endocrinol. Metab. 2012, 97, 1109-1113. [CrossRef]

87. Ye, P.; Yamashita, T.; Pollock, D.M.; Sasano, H.; William, E.; Rainey, W.E. Contrasting effects of eplerenone and spironolactone on adrenal cell steroidogennesis. Horm. Metab. Res. 2009, 41, 35-39. [CrossRef]

88. Ammirati, E.; Contri, R.; Coppini, R.; Cecchi, F.; Olivotto, I. Pharmacological treatment of hypertrophic cardiomyopathy: Current practice and novel perspectives. Eur. J. Heart Fail. 2016, 18, 1106-1118. [CrossRef]

89. Maron, B.J. Clinical course and management of hypertrophic cardiomyopathy. N. Engl. J. Med. 2018, 379, 655-668. [CrossRef]

90. Geske, J.B.; Ommen, S.R.; Gersh, B.J. Hypertrophic cardiomyopathy: Clinical update. JACC Heart Fail. 2018, 6, 364-375. [CrossRef]

91. Kitaoka, H.; Kubo, T.; Doi, Y.L. Hypertrophic cardiomyopathy-A heterogeneous and lifelong disease in the real world. Circ. J. 2020, 84, 1218-1226. [CrossRef]

92. Tuohy, C.V.; Kaul, S.; Song, H.K.; Nazer, B.; Heitner, S.B. Hypertrophic cardiomyopathy: The future of treatment. Eur. J. Heart Fail. 2020, F22, 228-240. [CrossRef]

93. Huang, C.Y.; Yang, Y.H.; Lin, L.Y.; Tsai, C.T.; Hwang, J.J.; Chen, P.C.; Lin, J.L. Renin-angiotensin-aldosterone blockade reduces atrial fibrillation in hypertorphic cardiomyopathy. Heart 2018, 104, 1276-1283. [CrossRef] [PubMed]

94. Alexandre, J.; Dolladille, C.; Douesnel, L.; Font, J.; Dabrowski, R.; Shavit, L.; Legallois, D.; Funck-Brentano, C.; Champ-Rigot, L.; Ollitrault, P.; et al. Effects of Mineralocorticoid Receptor Antagonists on Atrial Fibrillation Occurrence: A systematic review, meta-analysis, and meta-regression to identify modifying factors. Am. Heart Assoc. 2019, 8, e013267. [CrossRef]

95. Tsybouleva, N.; Zhang, L.; Chen, S.; Patel, R.; Lutucuta, S.; Nemoto, S.; DeFreitas, G.; Entman, M.; Carabello, B.A.; Roberts, R.; et al . Aldosterone, through novel signaling proteins, is a fundamental molecular bridge between the genetic defect and the cardiac phenotype of hypertrophic cardiomyopathy. Circulation 2009, 109, 1284-1291. [CrossRef] [PubMed]

96. Brown, N.J. Contribution of aldosterone to cardiovascular and renal inflammation and fibrosis. Nat. Rev. Nephrol. 2013, 9, 459-469. [CrossRef] [PubMed]

97. Sztechman, D.; Czarzasta, K.; Cudnoch-Jedrzejewska, A.; Szczepanska-Sadowska, E.; Zera, T. Aldosterone and mineralocorticoid receptors in regulation of the cardiovascular system and pathological remodelling of the heart and arteries. J. Physiol. Pharmacol. 2018, 69. [CrossRef] 
98. Takeda, Y. Pleiotropic actions of aldosterone and the effects of eplerenone, a selective mineralocorticoid receptor antagonist. Hypertens. Res. 2004, 27, 781-789. [CrossRef]

99. Takeda, Y.; Yoneda, T.; Demura, M.; Miyamori, I.; Mabuchi, H. Cardiac aldosterone production in genetically hypertensive rats. Hypertension 2000, 36, 495-500. [CrossRef]

100. Yoshimura, M.; Nakamura, S.; Ito, T.; Nakayama, M.; Harada, E.; Mizuno, Y.; Sakamoto, T.; Yamamuro, M.; Saito, Y.; Nakao, K.; et al. Expression of aldosterone synthase gene in failing human heart: Quantitative analysis using modified real-time polymerase chain reaction. J. Clin. Endocrinol. Metab. 2002, 87, 3936-3940. [CrossRef]

101. Garnier, A.; Bendall, J.K.; Fuchs, S.; Escoubet, B.; Rochais, F.; Hoerter, J.; Nehme, J.; Ambroisine, M.L.; De Angelis, N.; Morineau, G.; et al. Cardiac specific increase in aldosterone production induces coronary dysfunction in aldosterone synthasetransgenic mice. Circulation 2004, 110, 1819-1825. [CrossRef]

102. Alesutan, I.; Voelkl, J.; Feger, M.; Kratschmar, D.V.; Castor, T.; Mia, S.; Sacherer, M.; Viereck, R.; Borst, O.; Leibrock, C.; et al. Involvement of vascular aldosterone synthase in phosphate-induced osteogenic transformation of vascular smooth muscle cells. Sci. Rep. 2017, 7, 2059. [CrossRef]

103. Cardona, A.; Baker, P.; Kahwash, R.; Smart, S.; Phay, J.E.; Basso, C.; Raman, S.V. Evidence of aldosterone synthesis in human myocardium in acute myocarditis. Int. J. Cardiol. 2019, 275, 114-119. [CrossRef] [PubMed]

104. McKenna, W.J.; Judge, D.P. Epidemiology of the inherited cardiomyopathies. Nat. Rev. Cardiol. 2021, 18, 22-36. [CrossRef] [PubMed]

105. Yotti, R.; Seidmanm, C.E.; Seidman, J.G. Advances in the genetic basis and pathogenesis of sarcomere cardiomyopathies. Annu. Rev. Genom. Hum. Genet. 2019, 20, 129-153. [CrossRef] [PubMed]

106. Frantz, E.D.C.; Prodel, E.; Braz, I.D.; Giori, I.G.; Bargut, T.C.L.; Magliano, D.C.; Nobrega, A.C.L. Modulation of the reninangiotensin-system in white aduoise tissue abd skeletal muscle: Forcus on exercise training. Clin. Sci. 2018, 132, $1487-1507$. [CrossRef] [PubMed]

107. Santos, R.A.S.; Sampaio, W.O.; Alzamora, A.C.; Motta-Santos, D.; Alenina, N.; Bader, M.; Campagnole-Santos, M.J. The ace2/angiotensin-(1-7)/mas axis of the renin-angiotensin system: Focus on angiotensin-(1-7). Physiol. Rev. 2018, 98, 505-553. [CrossRef] [PubMed]

108. Patel, V.B.; Zhong, J.C.; Grant, M.B.; Oudit, G.Y. Role of the ace2/angiotensin 1-7 axis of the renin-angiotensin system in heart failure. Circ. Res. 2016, 118, 1313-1326. [CrossRef]

109. Rivière, G.; Lienhard, D.; Andrieu, T.; Vieau, D.; Frey, B.M.; Frey, F.J. Epigenetic regulation of somatic angiotensin-converting enzyme by DNA methylation and histone acetylation. Epigenetics 2011, 6, 478-489. [CrossRef]

110. Mudersbach, T.; Siuda, D.; Kohlstedt, K.; Fleming, I. Epigenetic control of the angiotensin-converting enzyme in endothelial cells during inflammation. PLoS ONE 2019, 14, e0216218. [CrossRef]

111. Lam, D.; Ancelin, M.L.; Ritchie, K.; Saffery, R.; Ryan, J. DNA methylation and genetic variation of the angiotensin converting enzyme (ACE) in depression. Psychoneuroendocrinology 2018, 88, 1-8. [CrossRef] [PubMed]

112. Burford, N.G.; Webster, N.A.; Cruz-Topete, D. Hypothalamic-pituitary-adrenal axis modulation of glucocorticoids in the cardiovascular System. Int. J. Mol. Sci. 2017, 18, 2150. [CrossRef] [PubMed] 